\title{
The varied rate of response to dietary intervention in autistic children
}

\author{
Jørgen Klaveness ${ }^{1}$, Jay Bigam ${ }^{2}$, Karl L. Reichelt ${ }^{3 *}$ \\ ${ }^{1}$ Greåker, Norway \\ ${ }^{2}$ Edmonton, Canada \\ ${ }^{3}$ Department of Pediatric Research, University of Oslo Hospital, Oslo, Norway \\ Email: ${ }^{*}$ karlr@ulrik.uio.no
}

Received 4 December 2012; revised 10 January 2013; accepted 19 January 2013

Copyright (C) 2013 Jørgen Klaveness et al. This is an open access article distributed under the Creative Commons Attribution License, which permits unrestricted use, distribution, and reproduction in any medium, provided the original work is properly cited.

\begin{abstract}
Exorphins from casein and gluten have been found by HPLC and mass spectroscopy with fragmentation pattern in quickly frozen urine. Removing the proteins that contain these peptides, by dietary intervention has been tried with behavioral effects. We wanted to know how fast such changes take place. Method: Parents and caregivers filled out ATEC scores (Autism treatment evaluation checklist) over time so that changes in scores could be registered. Results: In this group of children who all responded to diet the time required for a positive effect was months rather than weeks. Conclusion: Short term interventions are probably a waste of time and money, and at least 3 - 6 months trials seem to be necessary.
\end{abstract}

Keywords: ATEC-Score; Autism; Casein; Diet; Gluten

\section{INTRODUCTION}

Exorphins from casein, glutenin and gliadin have been reported in urine from autistic children [1,2] using HPLC and spiking with standards. This has now been firmly established by the use of mass spectroscopy and fragmentation mass spectroscopy (MS/MS) [3], when precautions are taken to prevent peptidase activity in the urine by rapid freezing or adding $1 \%$ by volume concentrated acetic acid (In prep). Also antibodies especially of the IgA type have been found in autism against these same proteins [4-7], as well as expected physiological effects in animal models [8,9] It is therefore reasonable to remove the source of these peptides using gluten and casein free $\operatorname{diet}(\mathrm{GF} / \mathrm{CF})$.

There are several open and positive reports on gluten and casein free diet $[2,8-14]$. Controlled single blind ei-

*Corresponding author. ther paired or grouped randomly assigned studies $[15,16]$ have been published. One study was followed up for 4 years [17], to counter placebo effects, which are not very likely after such a long time. However, trials that turned out negative so far have employed GF/CF diet for only a few weeks $[18,19]$. Due to experiments on semi-chronic schizophrenic patients, where it took 28 weeks to normalize their peptiduria [20], we suspect that sufficient time is a major factor when intervening with a GF/CF diet. This report therefore tries to document the rate of improvement in a group of children on GF/CF diet. We did not obtain any negative cases, and the parents would probably not participate in such cases.

\section{PATIENTS AND METHODS}

Parents and caregivers who had taken an interest in the GF/CF diet by joining the GFCFKIDS discussion group at www.yahoo.com, were encouraged to fill out an online survey before starting dietary intervention, and at regular intervals thereafter. The survey was based on the ATEC (Autism Treatment Evaluation Checklist), developed by ARI (the Autism Research Institute in San Diego, USA) and freely available at www.autism.com/atec/index.html. The ATEC score sheet is considered to have high general reliability (http:/www.autism.com/arec/report1.html). Parents or caregivers have used it for several years to report on the effectiveness of treatment alternatives [21].

The checklist was filled in by the parents and/or caregivers themselves. Responses to the survey were gathered in a secure database on line (set up by Bigam) and analyzed by Klaveness. A reasonably high number reported in first time at the start of dieting, before any effects were known. These conformed to the general pattern and strengthen the data. All the children had an official diagnosis within the autism spectrum (DSMIV and ICD 10). 
Complience is a problem because gluten and gliadin is widely used a thickener, to add body to fluids, soups etc. Also starch sold as gluten free may contain up to $1 \%$ by weight of wheat, which many celiacs tolerate. In short, we do not know how strict the diets really were. Reported complience is generally very unreliable. Even in a metabolic ward, strict diet does at times pose problems. When dietary infringements did take place, the time before symptoms reappeared, was registered.

Of the original group of 137 children, seven were eliminated from the calculations since their age was 1 year old at the start, and the diagnosis of autism at that age is uncertain and difficult. The participants all had official diagnoses of autism covered by ICD-10 registrations F84.0 and F 84.1.

The age range will be seen from Table 1. Average \pm $\mathrm{SD}=4.75 \pm 2.49(\mathrm{n}=130)$.

Statistics: Instat program was used throughout. When the collected data did not show normal distribution, non parametric statistics were used (Mann Whitney U test). If the distribution was normal, $t$ test was used, but when the standard deviations differed significantly the Welch correction for the t-test was employed...

Ethics: The data were volunteered from parents and collected by the parents. (Parent driven effort) .We also have ethical committee clearance for the study of psychiatric and neurological disorders (S-06270a) for south eastern Norway.

\section{RESULTS}

Overall results of collected data can be seen in Table 1. The difference in ATEC score before and after is highly significant (unpaired t-test with a $\mathrm{p}$ value $<0.001$ with Welch correction for unequal SD, and normal distribution of data.

The initial score compared to the last score obtained is statistically very different with a highly significant $p$ value of $0.001(\mathrm{n}=130)$ two tailed. The average decrease pr month $=2.9$ points. Given the average rate and comparing this to the average initial score it is obvious that many months must be necessary for significant improvements (Table $\mathbf{1}$ ).

In Table 2 we looked at children with ATEC score less than 50 points before and after intervention, the $p$ value is $<0.001$ and $n=28$. For those with ATEC scores higher than 100 points non-parametric statistics had to be used. $\mathrm{n}=28$ and Mann Whitney $\mathrm{U}=3.00$ and $\mathrm{U}^{\prime}=781.00$

Table 1. Overall changes found.

\begin{tabular}{|c|c|c|c|c|c|c|}
\hline Item & $\begin{array}{l}\text { Age at } 1 \mathrm{st} \\
\text { registration }\end{array}$ & $\begin{array}{c}\text { Initial } \\
\text { score }\end{array}$ & $\begin{array}{l}\text { Last } \\
\text { score }\end{array}$ & $\begin{array}{c}\text { Registration interval } \\
\text { (months) }\end{array}$ & $\begin{array}{c}\text { Numerical decrease } \\
\text { in ATEC score }\end{array}$ & $\begin{array}{l}\text { Percent } \\
\text { decrease }\end{array}$ \\
\hline mean & 4.75 & 76.1 & 41.26 & 10.01 & -35.25 & 41.85 \\
\hline Number & 130 & 130 & 130 & 130 & 130 & 130 \\
\hline $95 \%$ Conf Interval lower & 4.32 & 70.79 & 37.61 & 7.69 & -39.06 & 37.30 \\
\hline $95 \%$ Conf Interval upper & 15 & 81.43 & 44.91 & 12.33 & -40.45 & 46.39 \\
\hline Passed normality test & No & Yes & Yes & No & No & Yes \\
\hline Minimum & 2.00 & 8.00 & 6.00 & 0.25 & +12 & -36.00 \\
\hline Maximum & 15.00 & 154.00 & 103.00 & 120.00 & -147.00 & 96.00 \\
\hline
\end{tabular}

Table 2. Comparing children with ATEC scores $>100$ with scores $<50$ (The last four columns).

\begin{tabular}{|c|c|c|c|c|c|c|c|c|}
\hline Item & Age at start & ATEC at start & Months on diet & ATEC after diet & Age at start & ATEC at start & Months on diet & ATEC after diet \\
\hline Mean & 4.84 & 121.89 & 17.61 & 46.37 & 5.36 & 37.89 & 7.56 & 25.32 \\
\hline $\mathrm{N}=$ & 28 & 28 & 28 & 28 & 28 & 28 & 28 & 28 \\
\hline $95 \%$ CI upper & 6.96 & 127.57 & 27.15 & 13.0 & 6.4 & 41.97 & 9.81 & 29.84 \\
\hline 95\% CI Lower & 3.61 & 116.21 & 8.06 & $4 . .0$ & 4.32 & 33.82 & 5.31 & 20.8 \\
\hline Minimum & 2.00 & 100.00 & 1.00 & 7.00 & 2.00 & 8.00 & 0.5 & 6.0 \\
\hline Maximum & 13.00 & 154.00 & 120.00 & 163.00 & 15.00 & 50.00 & 24.0 & 47.0 \\
\hline Normality & No & Yes & No & No & No & Yes & No & Yes \\
\hline
\end{tabular}


and $\mathrm{p}<0.0001$ (two tailed).

The 28 highest scores on ATEC compared to the 28 lowest scores (Table 2).

Comparing the group scoring higher than 100 with the group scoring at the start less than 50, the rate of decrease was again different. The high scoring group had a monthly decrease of 4.4 units per month, while the low scoring group had a monthly decrease of 1.6 points per month. It is therefore obvious that long observation period especially in the high functioning children is a necessity.

Rate of change per month for the whole group can be seen in Table 1. The relationship of age to decrease in rating scale had to be calculated nonparameterically and the Spearman coefficient $r=-0.2482$ (corrected for ties) was very significant and different from zero with a $p$ value $=0.0059$.

The attached figure (Figure 1) compiled by J. Klaveness and Bigam show this graphically. The $\mathrm{Y}$ axis score is Rimlands ATEC score and the $\mathrm{X}$ axis is the time intervals in months. The parents reported the scores over the internet. A conference report has been published in proceedings of that meeting [20].

The best reacts one third of the autistic children (Figure 1).

Infringements are extremely difficult to detail. However, the time elapsed after accidentally or intentionally breaking the diet, and the appearance of symptoms, can be seen in Table 3. Hyperactivity, aggression and emotional aloofness seemed to be the cardinal symptoms.

Of the total participants 16 did not answer questions about dietary breaks etc. Those that answered made up $86.7 \%$ of the total. We do not know why there are such large differences (Table 3).

\section{DISCUSSION}

The respondents are not a random sample of parents or caregivers. Persons, who think they see changes in their autistic children, are probably more likely to respond to the survey and fill out the ATEC score sheet. The figure cannot tell us anything about those who did not respond at all, and where the parents may be suspected of not reporting in their autistic children's data. The survey can therefore not be used to determine the percentage of children that will improve on a GF/CF diet, or how much the average child will improve. It can, however, be used to make two other predictions, that should be taken into consideration when future studies are designed.

The first is that if the positive effect of the GF/CF diet that is reported in this survey is real, it does not seem to be a very rare phenomenon. It is fully possible that enthusiastic parents have over-estimated the effects. The

Table 3. Time elapsed after dietary infringement to noticed symptoms.

\begin{tabular}{lcc}
\hline Less than 30 min & 14 & $13 \%$ \\
30 min to 3 hours & 34 & $33 \%$ \\
3 - 12 hours & 31 & $30 \%$ \\
More than 12 hours & 25 & $24 \%$ \\
Total that answered & 104 & $100 \%$ \\
\hline
\end{tabular}

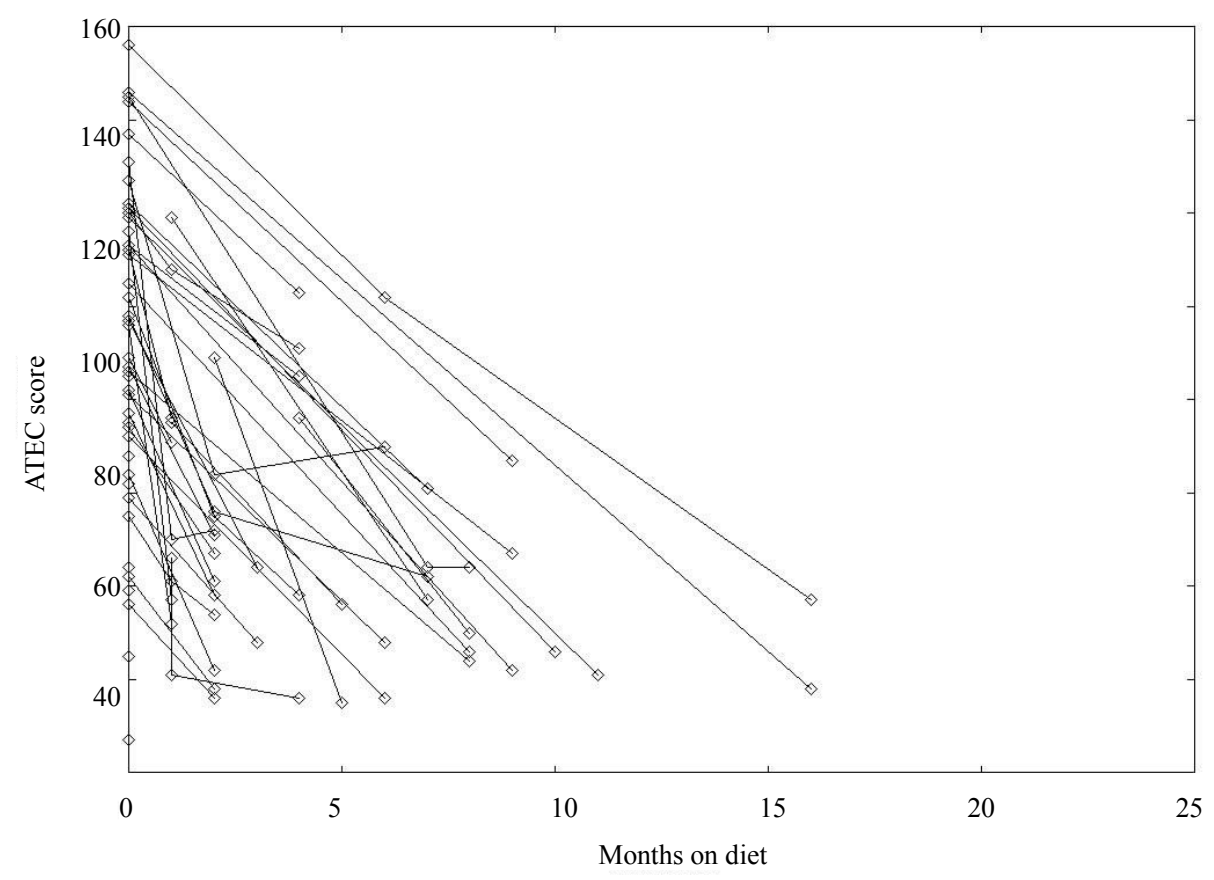

Figure 1. The ATEC score is plotted along the ordinate against months on diet along the abscissa. 
effect is so strong however, that it would still be highly significant if divided by a factor of 10 . If the diet is helpful for some children, the effect ought therefore to be common enough to be observable in relatively small study groups.

The second is that future studies must allow for the possibility that the helpful effect of the diet is slow to materialize, and that it could be seen at very different rates in different children. This is demonstrated by this report (Figure 1). These data conform to studies on semichronic schizophrenic patients where it took 28 weeks to completely normalize the urine pattern and levels [20] though behavioral changes were registered earlier. This prediction would be equally reasonable since a change in physiology still demands relearning of social skills. Morphological changes in the brain, for example, need considerable time to be ameliorated. Antibodies against food proteins have very different rates of decrease, and antibodies to gliadin also have effects on cerebellar Purkinje cells [22].

A dietary effect is a physiological and biochemical possibility and probability has been documented [23,24]. We do not know why the variation in improvement is so great. However there may be problems of compliance especially in the most severely ill group. Furthermore studies of those with $\operatorname{IgA}$ and or $\operatorname{IgG}$ antibody increases [4-7] indicate that a subgroup show increased protein uptake from the gut, and we suspect that breaks in the diet takes more time to recover (preliminary observations). Since there is a correlation of severity of autism and peptide levels [25], we may suspect that it takes more time to correct or ameliorate damaged CNS function. Casomorphins cause FOS antigen activation in the CNS [26] blocked by naloxone, and opioids interfere with brain maturation [27]. Thus it seems from the collected data that the higher the initial score the slower the improvement. This is also what is found by Pennessi [14].

\section{CONCLUSION}

For the members of the internet survey, who reported in using the ATEC scores, as seen in Figure 1 and Table 1, it is clear that some show very slow improvement. 14 days interventions are a waste of time, as it takes time to get used to what is permissible to eat.

\section{REFERENCES}

[1] Reichelt, K.1. and Knivsberg, A.-M. (2003) Can the pathophysiology of autism be explained by the nature and the discovered urine peptides? Nutritional Neuroscience, 6, 19-28. doi:10.1080/1028415021000042839

[2] Cade, R., Private, Fregly, M., Rowland, N., Sun, Z., Zele, V., Wagemaker, H. and Edelstein, C. (2000) Autism and schizophrenia: Intestinal disorders. Nutritional Neurosci- ence, 3, 57-72.

[3] Reichelt, K.L., Tveiten, D., Knivasberg, A.-M. and Brønstad, G. (2012) Peptides role in autism with emphasis on exorphins. Microbial Ecology in Health and Disease, 23, 2012. doi:10.3402/mehd.v23i0.18958

[4] Reichelt, K.L., Ekrem, J. and Scott, H. (1990) Gluten, milk proteins and autism: Dietary intervention effects on behavior and peptide secretion. Journal of Applied Nutrition, 42, 1-11.

[5] Kawashti, M.I., Amin, O.R. and Rowehy, N.G. (2006) Possible immunological disorders in autism: Concomitant autoimmunity and immune tolerance. Egyptian Journal of Immunology, 13, 99-104.

[6] Traikovski, V., Petichoski, A., Efinska-Mladenovskia, O., Trajkov, D., Arsov, T. and Strezova, A. (2008) Higher plasma concentration of food-specific antibodies in persons with autistic disorder in comparison to their siblings. Focus on Autism and Other Developmental Disabilities, 23, 176-186. doi:10.1177/1088357608320413

[7] Vojdani, A., O’Bryan, T., Green, J.A., Mc Candless, J., Woeller, K.N., Vojdani, E., Nourian, A.A. and Cooper, E.L. (2004) Immune response to dietary proteins, gliadin and cerebellar peptides in children with autism. Nutritional Neuroscience, 7, 151-161.

[8] Knivsberg, A.-M., Wiig, K., Lind, G., Nødland, M. and Reichelt, K.L. (1990) Dietary intervention in autistic syndromes. Brain Dysfunction, 3, 315-327.

[9] Reichelt, K.L., Knivsberg, A.-M., Lind, G. and Nødland, M. (1991) Probable etiology and possible treatment of childhood autism. Brain Dysfunction, 4, 308-319.

[10] Lucarelli, S., Frediani, T., Zingoni, A.M., Ferruzzi, F., Giardini, O., Quintieri, F., Barbato, M., D’Eufemia, P. and Cardi, E. (1995) Food allergy and infantile autism. Panminerva Medica, 37, 137-141.

[11] Kniker, W.T., Andrews, A., Hundley, A. and Garver, C. (2001) The possible role of intolerance to milk/dairy and wheat/gluten foods in older children and adults with autism spectrum disorder. An autism odyssey. The Autism Research Unit, Sunderland University, 183-191.

[12] Whiteley, P., Rodgers, J., Savery, D. and Shattock, P. (1999) A gluten-free diet as an intervention for autism and associated spectrum disorders: Preliminary findings. Autism, 3, 45-65. doi:10.1177/1362361399003001005

[13] Slimak, K.M. (2003) Reduction of autistic traits following dietary intervention and elimination of exposure to environmental substances. Proceedings of International Symposium on Indoor Air Quality and Health Hazards, Tokyo, 8-11 January 2003, pp. 206-216.

[14] Pennesi, C.M. and Klein, C. (2012) Effectiveness of the gluten-free, casein-free diet for children diagnosed with autism spectrum disorder: Based on parental report. $\mathrm{Nu}$ tritional Neuroscience, 15, 85-91. doi:10.1179/1476830512Y.0000000003

[15] Knivsberg, A.-M., Reichelt, K.L., Høien, T. and Nødland, M. (2002) A Randomized, controlled study of dietary intervention in autistic syndromes. Nutritional Neuroscience, 5, 251-261. doi:10.1080/10284150290028945

[16] Whiteley, P., Haracopos, D., Knivsberg, A.-M., Reichelt, 
K.L., Parlar, S., Jacobsen, J., Seim, A., Pedersen, L., Schondel, M. and Shattock, P. (2010) The ScanBrit randomized, controlled, single-blind study of a gluten-and casein-free dietary intervention for children with autism spectrum disorders. Nutritional Neuroscience, 13, 87-100. doi:10.1179/147683010X12611460763922

[17] Knivsberg, A.-M., Reichelt, K.L., Nødland, M. and Høien, T. (1995) Autistic syndromes and diet: A follow-up study. Scandinavian Journal of Educational Research, 39, 223236.

[18] Johnson, C.R., Handen, B.L., Zimmer, M., Sacco, K. and Turner, K. (2011) Effects of gluten free/casein free diet in young children with autism: a pilot study. Journal of Developmental and Physical Disabilities, 23, 213-225. doi:10.1007/s10882-010-9217-x

[19] Elder, J.H., Shankar, M., Shuster, J., Theriaque, D., Burns, S. and Sherril, L. (2006) Review of the gluten-free, casein-free diet in autism: Results of a preliminary double blind trial. Journal of Autism and Developmental Disorders, 16, 413-420. doi:10.1007/s10803-006-0079-0

[20] Reichelt, K.L., Sagedal, E., Landmark, J., Tshumi-Sangvik, B., Eggen, O. and Scott, H. (1990) The effect of a gluten free diet on glycoprotein associated urinary peptide excretion in schizophrenia. Journal of Orthomolecular Medicine, 5, 223-239.

[21] Rimland, B. (2003) Parents rating of the behavioral effects of biomedical interventions. Autism Institute Reports.

[22] Klaveness, J. and Bigam, J. (2002) The GFCF kids diet survey. In: Building Bridges. The Autism Research Unit and Autism North Ltd., Sunderland, 77-84.

[23] Hadjivassiliou, M., Boscolo, S., Davies-Jones, G.A.B., Grünewald, R.A., Not, T., Sandea, D.S., Simpson, J.E., Tongiorgi, E., Williamson, C.A. and Woodroofe, N.M. (2002) The humeral response in the pathogenesis of gluten ataxia. Neurology, 58, 1221-1226. doi:10.1212/WNL.58.8.1221

[24] Reichelt, K.L. and Knivsberg, A.-M. (2009) The possibility and probability of a gut-to-brain connection in autism. Annals of Clinical Psychiatry, 21, 205-211. https://www.aacp.com/pdf\%2F2104\%2F2104ACP_Revie w1.pdf

[25] Sacco, R., Curatolo, P., Manzi, B., Militerni, R., Bravaccio, C., Frolli, A., Lenti, C., Saccani, M., Elia, M., Reichelt, K.L., Pscucci, T., Puglisi-Allegra, S. and Persico, A.M. (2010) Principal pathogenic components and biological endophenotypes in autism spectrum disorders. $\mathrm{Au}$ tism Research, 3, 237-252. doi:10.1002/aur.151

[26] Sun, Z., Cade, R.J., Firefly, M.J. and Privette, R.M. (1999) Beta casomorphin induces fos-like immunoreactivity in discrete brain regions relevant to schizophrenia and autism. Autism, 3, 67-83. doi:10.1177/1362361399003001006

[27] Hauser, K.F., McLaughlin, P.J. and Zagon, I.S. (1989) Endogenous opioid systems and the regulation of dendritic growth and spine formation. Journal of Comparative Neurobiology, 281, 13-22. doi:10.1002/cne.902810103 